\title{
Effects of trees and nitrogen supply on the soil microbiological attributes on integrated crop-livestock systems ${ }^{1}$
}

\author{
Ana Paula Zandona 2 , Arnaldo Colozzi Filho ${ }^{2}$, Laíse da Silveira Pontes ${ }^{3 *}$ (D) \\ $10.1590 / 0034-737 X 201966030009$
}

\begin{abstract}
The diversification of plants, as an association between trees and the warm-season grasses, supports soil biodiversity and thus, soil quality. However, based on the prevailing climatic conditions, management techniques employed and because of the several combinations possible in such associations, variations may be observed in this type of response. This study aimed at assessing the microbiological attributes of the soil in two systems (full sunlight, FS, vs. a naturally shaded system composed of Eucalyptus dunnii trees), with two $\mathrm{N}$ fertilization levels (zero vs. $300 \mathrm{~kg} \mathrm{~N}^{-1} \mathrm{year}^{-1}$ ) and five perennial warm-season grasses. Soil and root samples were drawn from a depth of 0 to $20 \mathrm{~cm}$ when the growing period began. The $\mathrm{N}$ fertilization increased the mycorrhizal colonization and the acid phosphatase activity, whereas lowered the soil microbial biomass. A rise in the mycorrhizal colonization and sporulation and $\mathrm{C}$ microbial biomass concentration were observed in the soil cultivated with Axonopus catharinensis. The association with trees favored the arbuscular mycorrhizal fungal communities, boosting both colonization and sporulation. However, compared with the FS, the soil microbial biomass and activity of the acid phosphatase enzyme were reduced under the trees. Silvicultural interventions could be intensified to enhance soil quality.
\end{abstract}

Keywords: acid phosphatase; agroforestry; arbuscular mycorrhizal fungi; glomalin; microbial biomass; tropical grasses.

\section{INTRODUCTION}

A strongly intensifying interest is generally being directed towards integrated crop-livestock systems (ICLS), as they have the potential to achieve synergisms and emerging characteristics resulting from the soil-plant-animal-atmosphere interactions (Carvalho et al., 2010; Moraes et al., 2014). The challenge at present is to clarify the complete dynamics of such systems, i.e. the strength with which the different interactions occur among their various constituents and their effects on the tree, forage, animal and agricultural outputs, as well as in the provision of ecosystem services.

The high potential of ICLS is evident from the integration of trees with the tropical perennial pastures. Therefore, this type of system is gaining interest (Pretty,
2018), mostly because of the necessity to recover degraded pastures, specifically in the tropical / subtropical soils, and environmental restrictions to explore new regions of native vegetation. The incorporation of trees in pastures contributes to animal welfare (Lopes et al., 2016), C sequestration both in the soil and in tree woody biomass (Udawatta \& Jose, 2012), plant diversification and litter accumulation (Freitas et al., 2013), decrease in the soil erosion processes and utilization of the nutrients from the deeper soil layers, thus improving soil biological processes (Araujo et al., 2012). In fact, the relationship among the perennial species facilitates permanent litter deposits, thus raising the organic content and positively affecting the soil microbial community due to the increased $\mathrm{C}$ sources and energy (Araujo et al., 2012). Bainard et al. (2011) proposed that the tree systems encouraged the

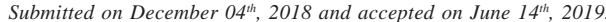

${ }^{1}$ This work is part of the first author Master's dissertation.

Instituto Agronômico do Paraná, Londrina, Paraná, Brazil. anapaulazandon@ @otmail.com; acolozzi@iapar.br;

3 Instituto Agronômico do Paraná, Ponta Grossa, Paraná, Brazil. laisepontes@iapar.br

*Corresponding author: laisepontes@iapar.br
} 
abundance of the arbuscular mycorrhizal fungi (AMF) to a greater degree than did the conventional farming systems. However, the same authors emphasized that such a response could vary, principally because of climate variations, management techniques and a variety of possible combinations in such associations (e.g., tree arrangements and tree species, tree density and age, etc.).

The association of trees with pastures in general appears to induce a positive change in the soil quality through higher chances for nutrient cycling (Batista et al., 2018). However, microclimate alterations within the system and therefore water availability, together with the competition between trees and intercropping for light and nutrients may influence the quantity and quality of the organic residues deposited on the soil, besides their spatial distribution and hence, the resultant microbiological attributes. Thus, data on the manner in which the tree systems and such types of more sustainable production practices affect the microbial community and populations like AMF continue to be required (Ferreira $e t$ al., 2012).

According to Pontes et al. (2016) different responses with regards to forage production and nutritive values were noted when several different $\mathrm{C}_{4}$ forages were used, besides the interactive influence of the Eucalyptus dunnii shading and added nitrogen $(\mathrm{N})$ doses. Thus, as all the observations made above the ground level are mirrored below the soil, it is possible that any alteration in the microbiological attributes occur in response to the different forages when in association with the trees. Besides, the traits of the host plant affect the occurrence of the AMF (Staddon et al., 2003). The glomalin, a glycoprotein produced by the AMF in the soils, is affected by the relationship between fungi and plants (Sousa et al., 2012). The "glue" effect of the glomalin enables the soil particles to get fixed, facilitating the formation of stable aggregates (Driver et al., 2005; Sousa et al., 2012).

The present study assessed the microbiological attributes of the soil under a variety of production systems, that is, monoculture vs. a system which included $E$. dunnii, raised with two doses of $\mathrm{N}$ and five perennial tropical forage grasses. The hypothesis proposed in this work is that the microbiological attributes of the soil are positively affected by afforestation and $\mathrm{N}$ fertilization, either via increased litter deposition or diversification of the vegetal residues on the soil, although these responses are species-dependent.

\section{MATERIAL AND METHODS}

The experiment was performed in an area within the Agronomic Institute of Paraná, in Ponta Grossa, in the Center-South region of the state of Paraná $\left(25^{\circ} 06^{\prime} \mathrm{S}\right.$, and $50^{\circ} 02^{\prime} \mathrm{W}$ at $1019 \mathrm{~m}$ altitude). Based on the Köppen classification, the climate of the region is type $\mathrm{Cfb}$, meaning subtropical and no dry season. The mean temperature and rainfall data, during the experimental period, are shown in Table 1.

The experimental area is characterized by umbric Dystrophic Red Latosol (Embrapa, 2008). The main chemical features of the soil during the experiment are seen in Table 2.

The production systems investigated were done under full sun conditions (FS, i.e., perennial tropical forage monocultures) and the integrated crop-livestock system with trees (ICLS, implying the association between the tropical perennial forage species and $E$. dunnii). The five $\mathrm{C}_{4}$ perennial forage grass species studied are generally cultivated in the Brazilian livestock and include, Axonopus catharinensis Valls., (Ac), Urochloa brizantha cv. Marandu (Ub), Cynodon spp. hybrid Tifton 85 (Cs), Hemarthria altissima (Poir.) Stapf \& Hubb cv. Flórida (Ha) and Megathyrsus maximus Jacq. cv. Aruana (Mm), planted in 2010 in $4.5 \mathrm{~m}^{2}$ plots, under FS and $105 \mathrm{~m}^{2}$ (5 x $\left.21 \mathrm{~m}\right)$ between the lines of the $E$. dunnii trees. The trees were planted in 2007, with an initial density of 267 trees ha-1, according to a double row arrangement using $3 \mathrm{~m}$ between the trees within rows and $4 \mathrm{~m}$ between the rows. These double rows sets were spaced $21 \mathrm{~m}$ apart ( 3 by 4 by $21 \mathrm{~m}$ ), following the contour. In 2011, the thinning done during the winter, decreased the population to 219 trees $\mathrm{ha}^{-1}$, while the thinning performed in the summer of 2014 cut the population down to 155 trees $\mathrm{ha}^{-1}$.

After the application of two doses of $\mathrm{N}(0$ and $300 \mathrm{~kg}$ of $\mathrm{N} \mathrm{ha}^{-1}$ year $^{-1}$, N0 and N300, respectively), as urea, with three replicates, six plots per species were formed for each system. The ICLS also included three distances between the tree rows, viz., P2, position adjacent to the rows ( $2 \mathrm{~m}$ away from an arboreal row); P5, intermediate position (at $5 \mathrm{~m}$ distance); and P10, central position between two tree rows (10.5 $\mathrm{m}$ away from the tree rows). Two ceptometers (LP-80 AccuPAR, Decagon Equipment Co, Pullman WA) were used to calculate the shading percentages (percent reduction of the photosynthetically active radiation, PAR) one of which was kept in the FS region while the other was placed under the tree canopy, in each position. On March 17, 2016 four evaluations were performed between 10 and 11:30 AM and four more between 1:30 and 3:00 PM per position, at $1 \mathrm{~m}$ above soil level, in three experimental woody units per block. The decrease in light availability for the understory vegetation was calculated as the difference in the values from these two ceptometers, according to Pontes et al. (2016).

Based on the soil analysis, fertilization was done in each area considering the specified recommendations for the crops. Liming was conducted to raise the saturation 
of the bases to $70 \%$. In the spring, $60 \mathrm{~kg}$ of $\mathrm{P}_{2} \mathrm{O}_{5} \mathrm{ha}^{-1}+60$ $\mathrm{kg}$ of $\mathrm{K}_{2} \mathrm{O} \mathrm{ha}^{-1}$ were added, independently of the treatments assessed prior to collecting the soil samples for the microbiological analyses. $\mathrm{N}$, as urea, was added depending upon the treatments, on October 23, 2015. Please refer to Pontes et al. (2016) for further information on fertilization and pasture and tree management in the experiment since its implantation.

In November 2015, soil and root samples were taken with a spade ( $20 \mathrm{~cm}$ width, $\sim 1 \mathrm{~kg}$ ), ensuring that the sample had the same width at the top and bottom of slice, from a depth of $0-20 \mathrm{~cm}$, one month post the standardization cutting of the pastures (at the same regrowth age, in order to better compare the different species). Only one sample per experimental unit was collected in the FS system. The choice for collecting one representative point per plot under FS was because of the reduced areas of the plots. However, three simple samples per experimental unit were collected in the ICLS, considering the three positions between the tree double rows mentioned previously. This was most likely done because of the differences in the PAR transmitted between the tree rows $(21 \mathrm{~m}$ between two rows). The fresh soil samples were sieved through a $4 \mathrm{~mm}$ screen with large plant material removed and stored at $7{ }^{\circ} \mathrm{C}$ until analysis. Thin roots $(<2 \mathrm{~mm})$ were washed in water and stored in plastic receptacles containing 50\% alcohol, for preservation until the analysis.

To determine the carbon of the microbial biomass (MBC), the fumigation-extraction method (Vance et al., 1987) was employed, while the $\mathrm{N}$ analysis of the microbial biomass (MBN) was done following the method of Brookes et al. (1985). Both methods were modified before use, as explained by Hungria et al. (2009). The AMF root colonization (MC) was determined in stained roots under a stereoscopic microscope, based on the technique of Giovannetti \& Mosse (1980). The AMF spores number (SPO) was determined by the extraction from soil employing the wet sieving technique adopted by Gerdemann \& Nicolson (1963). The extraction of the total glomalin (TG) and easily extractable soil glomalin (EEG) was accomplished, using the method of Rillig et al. (2003). Glomalin quantification was done based on the methodology of Bradford (1976). The acid phosphatase was determined using the method adapted by Tabatabai (1994). The $\mathrm{NO}_{3}^{-}-\mathrm{N}$ levels in the soil were evaluated following the method of Miyazawa et al. (1985), while the $\mathrm{NH}_{4}{ }^{+} \mathrm{N}$ contents were assessed with the method used by Kempers \& Zweers (1986).

The soil microbiological attributes were subjected to the analyses of variance using the split-split-plot-like

Table 1: Mean minimum-maximum monthly temperature $\left({ }^{\circ} \mathrm{C}\right)$ and total rainfall $(\mathrm{mm})$ during the experimental period $(2015)$ and historical mean $(\mathrm{MH})$

\begin{tabular}{lcccc}
\hline \multirow{2}{*}{ Months } & \multicolumn{4}{c}{ Temperature $\left({ }^{\circ} \mathbf{C}\right)$} \\
\cline { 2 - 5 } & $\mathbf{2 0 1 5}$ & MH (1998-2015) & $\mathbf{2 0 1 5}$ & MH (1998-2015) \\
\hline January & $19.6-36.0$ & $17.5-27.2$ & 136 & 158 \\
February & $18.7-33.0$ & $17.5-27.7$ & 162 & 170 \\
March & $17.4-31.6$ & $16.6-27.1$ & 180 & 120 \\
April & $13.8-29.3$ & $14.6-25.2$ & 74 & 97 \\
May & $13.0-24.5$ & $10.8-20.7$ & 174 & 106 \\
June & $9.8-23.8$ & $10.1-20.4$ & 73 & 110 \\
July & $10.5-21.9$ & $9.4-20.0$ & 273 & 74 \\
August & $10.6-28.4$ & $10.1-22.2$ & 35 & 140 \\
September & $13.5-30.7$ & $12.0-23.1$ & 131 & 160 \\
October & $17.0-28.0$ & $14.2-25.0$ & 177 & 130 \\
November & $17.7-28.5$ & $15.3-26.1$ & 237 & 143 \\
December & $18.6-31.4$ & $16.7-27.2$ & 167 & \\
\hline
\end{tabular}

Source: SIMEPAR, station 25135001, situated in the municipality of Ponta Grossa/PR.

Table 2: Chemical characterization of the soil, at 0-20 cm depth, under the full sun (FS) system and integrated crop-livestock system with trees (ICLS)

\begin{tabular}{|c|c|c|c|c|c|c|c|c|c|c|c|c|}
\hline \multirow{2}{*}{\multicolumn{2}{|c|}{$\mathbf{p H}$}} & OM & $\mathbf{P}$ & $\mathbf{K}$ & $\mathrm{Ca}^{2+}$ & $\mathrm{Mg}^{2+}$ & $\mathbf{A l}^{3+}$ & $\mathbf{H}+\mathbf{A} \mathbf{l}^{3+}$ & SB & $\mathbf{T}$ & $\mathbf{V}$ & SAI \\
\hline & & $\mathrm{g} \mathrm{kg}^{-1}$ & \multicolumn{2}{|c|}{$\mathrm{mg} \mathrm{dm}^{-3}$} & \multicolumn{6}{|c|}{$\mathrm{cmol}_{\mathrm{c}} \mathrm{dm}^{-3}$} & \multicolumn{2}{|c|}{$\%$} \\
\hline FS & 5.7 & 41.7 & 24.0 & 60.6 & 3.6 & 1.8 & 0.0 & 3.8 & 5.6 & 9.4 & 59.0 & 0.0 \\
\hline ICLS & 5.5 & 41.3 & 21.8 & 107.3 & 3.4 & 1.8 & 0.0 & 4.3 & 5.5 & 9.8 & 56.3 & 0.0 \\
\hline
\end{tabular}

OM, soil organic matter; SB, sum of bases; T, cation exchange capacity; V, base saturation; SAI, aluminum saturation. P-K (MEHLICH 1); Ca-Mg-Al ( $\left.\mathrm{KCl} 1 \mathrm{~mol} \mathrm{~L}{ }^{-1}\right) ; \mathrm{pH}\left(\mathrm{CaCl}_{2}\right)$. 
model and employing the Statgraphics Centurion XV program (2006). While the systems (FS vs. ICLS, GL = 1) were regarded as the main plots, the $\mathrm{N}$ doses $(\mathrm{GL}=1)$ were used as the subplots and forages $(\mathrm{GL}=4)$ as sub-subplots. The error of the main plot was the block (system), while that of the subplot was the $\mathrm{N}^{*}$ block (system). The model included the position between two tree rows $(\mathrm{GL}=2)$ as a nested factor in the system. All the factors barring the block were regarded as fixed. Initially, all the interactions, excepting the one with the block were included in the statistical model. In the final model, the non-significant interactions were eliminated. To fulfill the normality test, all data were transformed into logarithms, the TG (transformed via Box-Cox) and mycorrhizal colonization (MC, no transformation needed) being the exceptions. In the event of a variable having a significant effect, the Fisher's least significant difference (LSD) test was done.

\section{RESULTS AND DISCUSSION}

Slight variations were noted, on average, between the systems and $\mathrm{N}$ doses in the MC ( $\mathrm{p}<0.10$, Tables 3 and 4). A significant part of the variance (18\%) for MC was defined by the species factor, with values in the range of $36 \%$ (Cs) to $50 \%$ (Ac, Table 5). These results signify a good amount of colonization in the grasses, with values corresponding to the findings in other studies (Cordeiro et al., 2005). However, as evident from Figure 1, marked interactions ( $\mathrm{p}<$ $0.01, F=4.03$ ) between the species, systems and $\mathrm{N}$ doses were observed for this variable. Therefore, it was difficult to identify, for instance, the species which showed the greater or lesser effectiveness in mycorrhization, because the colonization varied with the treatments. For example, in the ICLS, the N0 treatment, cv. Tifton 85 returned the least MC values ( 25\%), while in the FS, the N0 treatment, cv. Marandu gave the lowest values ( 27\%, Figure 1).

In MC, Tifton 85 showed the greatest differences between treatments (difference of $\sim 22 \%$ between ICLS N0 and FS N0, Figure 1). Pontes et al. (2016) also reported a higher amplitude of response, with respect to the aerial dry matter yield, for the same species used in the present experiment. Therefore, it is clear that association with tree and $\mathrm{N}$ fertilization impact the cv. Tifton 85 , both in terms of productivity, and the MC of this species, most likely revealed effects on root density. Indeed, Tifton 85 showed an important decrease (-53\%, data not shown) in root mass density ( 0 - $15 \mathrm{~cm}$ depth) in the ICLS compared to the FS system. The A. catharinensis, however, exhibited the

Table 3: Microbiological attributes of the soil (mean \pm standard deviation) of each system (FS, full sun, $n=30$, ICLS, integrated croplivestock system with trees, $\mathrm{n}=90$ ) are shown. Mycorrhizal colonization $(\mathrm{MC})$, sporulation by arbuscular mycorrhizal fungi (SPO), acid phosphatase (AP), easily extractable glomalin (EEG), total glomalin (TG), soil microbial biomass nitrogen (MBN) and carbon $(\mathrm{MBC})$ and soil inorganic $\mathrm{N}\left(\mathrm{NH}_{4}^{+}-\mathrm{N}^{-}\right.$and $\left.\mathrm{NO}_{3}^{-}-\mathrm{N}\right)$ are listed

\begin{tabular}{|c|c|c|c|c|}
\hline & FS & ICLS & $\mathbf{F}$ & $\mathbf{p}$ \\
\hline $\mathrm{MC}(\%)$ & $38 \pm 1.5$ & $42 \pm 1.3$ & 4.6 & 0.0994 \\
\hline $\mathrm{SPO}\left(50 \mathrm{~mL}^{-1}\right.$ soil $)$ & $27 \pm 2.6$ & $52 \pm 4.0$ & 18 & 0.0136 \\
\hline $\mathrm{AP}\left(\mu \mathrm{g}\right.$ p-nitrophenol $\mathrm{g}^{-1}$ soil $\left.^{-1}\right)$ & $363 \pm 14.0$ & $270 \pm 6.3$ & 51 & 0.0020 \\
\hline $\operatorname{EEG}\left(\mathrm{mg} \mathrm{g}^{-1}\right.$ soil $)$ & $2.6 \pm 0.05$ & $2.5 \pm 0.06$ & 0.3 & 0.6085 \\
\hline $\mathrm{TG}\left(\mathrm{mg} \mathrm{g}^{-1}\right.$ soil $)$ & $5.9 \pm 0.16$ & $4.6 \pm 0.16$ & 2.9 & 0.1630 \\
\hline $\operatorname{MBN}\left(\mu \mathrm{g} \mathrm{N} \mathrm{g}^{-1}\right.$ soil $)$ & $127 \pm 5.1$ & $99 \pm 4.4$ & 15 & 0.0186 \\
\hline $\operatorname{MBC}\left(\mu \mathrm{g} \mathrm{C} \mathrm{g}^{-1}\right.$ soil $)$ & $179 \pm 9.0$ & $158 \pm 5.9$ & 1.7 & 0.2638 \\
\hline $\mathrm{NH}_{4}^{+}-\mathrm{N}\left(\mu \mathrm{g} \mathrm{g}^{-1}\right.$ soil $)$ & $3.3 \pm 0.12$ & $1.8 \pm 0.09$ & 4.9 & 0.0903 \\
\hline $\mathrm{NO}_{3}^{-}-\mathrm{N}\left(\mu \mathrm{g} \mathrm{g}^{-1}\right.$ soil $)$ & $38 \pm 2.9$ & $29 \pm 1.4$ & 7.2 & 0.0552 \\
\hline
\end{tabular}

$\mathrm{F}$ and $\mathrm{p}, \mathrm{F}-\mathrm{ratio}$ and probability for the system effect.

Table 4: Microbiological attributes of the soil (mean \pm standard deviation) at different $\mathrm{N}$ rates (N0, without nitrogen fertilization, $\mathrm{N} 300,300 \mathrm{~kg} \mathrm{~N}^{-1} \mathrm{year}^{-1}, \mathrm{n}=60$ ). Refer to Table 3 for abbreviations

\begin{tabular}{lcccc}
\hline & N0 & N300 & F & p \\
\hline $\mathrm{MC}(\%)$ & $38 \pm 1.7$ & $43 \pm 1.3$ & 6.5 & 0.0635 \\
$\mathrm{SPO}\left(50 \mathrm{~mL}^{-1}\right.$ soil $)$ & $55 \pm 5.1$ & $38 \pm 3.6$ & 3.5 & 0.1351 \\
$\mathrm{AP}(\mu \mathrm{g} \mathrm{p}$-nitrophenol g & -1 & 26 & 0.0072 \\
$\mathrm{EEG}\left(\mathrm{mg} \mathrm{g}^{-1}\right.$ soil $)$ & $271 \pm 8.5$ & $315 \pm 10.2$ & 0.4 & 0.5872 \\
$\mathrm{TG}\left(\mathrm{mg} \mathrm{g}^{-1}\right.$ soil $)$ & $2.5 \pm 0.06$ & $2.6 \pm 0.08$ & 2.8 & 0.1689 \\
$\mathrm{MBN}\left(\mu \mathrm{g} \mathrm{N} \mathrm{g}^{-1}\right.$ soil $)$ & $4.8 \pm 0.19$ & $5.0 \pm 0.20$ & 2.1 & 0.2195 \\
$\mathrm{MBC}^{-1} \mu \mathrm{g} \mathrm{C} \mathrm{g}^{-1}$ soil $)$ & $105 \pm 7.5$ & $108 \pm 4.6$ & 1.8 & 0.2462 \\
$\mathrm{NH}_{4}^{+}-\mathrm{N}\left(\mu \mathrm{g} \mathrm{g}^{-1}\right.$ soil $)$ & $171 \pm 8.0$ & $155 \pm 6.0$ & 12 & 0.0257 \\
$\mathrm{NO}_{3}^{-}-\mathrm{N}\left(\mu \mathrm{g} \mathrm{g}^{-1}\right.$ soil $)$ & $2.3 \pm 0.14$ & $2.1 \pm 0.13$ & 43 & 0.0028 \\
\hline
\end{tabular}

$\mathrm{F}$ and $\mathrm{p}, \mathrm{F}-\mathrm{ratio}$ and probability for the $\mathrm{N}$ doses effect. 
lowest variations among the treatments $(\sim 6 \%)$. Besides, this species demonstrated the highest values among all the treatments, except in the FS system, for N0 (Figure 1). The A. catharinensis forage seemed to have experienced higher photosynthetic efficiency in most of the treatments when compared with the other species, meaning, it had conducted photosynthesis in a symbiotic relationship with the AMF, maintaining a greater degree of colonization, to experience higher nutrient absorption levels, $\mathrm{P}$ in particular (Cordeiro et al., 2005).

The ICLS showed a remarkably greater number of AMF spores when compared to FS (Table 3), regardless of the plant species raised. Besides, only in the ICLS were differences noted in the $\mathrm{N}$ doses in sporulation by AMF, with increased values in the N0 treatment (please refer to Figure 2 for the results of the intense interactions between the systems and doses of $\mathrm{N}, \mathrm{p}<0.05, \mathrm{~F}=6.38)$. Sporulation is a perpetuation mechanism of the AMF species, which is stimulated when the plant and fungus experience some type of stress (Ferreira et al., 2012). Therefore, when they were exposed to multiple stresses (light and N) sporulation was induced. However, even in the treatment having higher sporulation, meaning, 65 in $50 \mathrm{~mL}$ of soil (ICLS N0, Figure 2), this value cannot be regarded as high, as reiterated by Santos et al. (2008). In fact, in their study using B. brizantha cv. Xaraés, Delbem et al. (2010) reported increased values for the number of spores (more than 146 per $100 \mathrm{~g}$ of dry soil). These authors also recorded a rise in sporulation in response to the high urea and ammonium sulfate doses added (400 $\mathrm{kg}$ of $\mathrm{N} \mathrm{ha}^{-1}$ ), implying stress caused by the raised $\mathrm{N}$ levels in the soil.

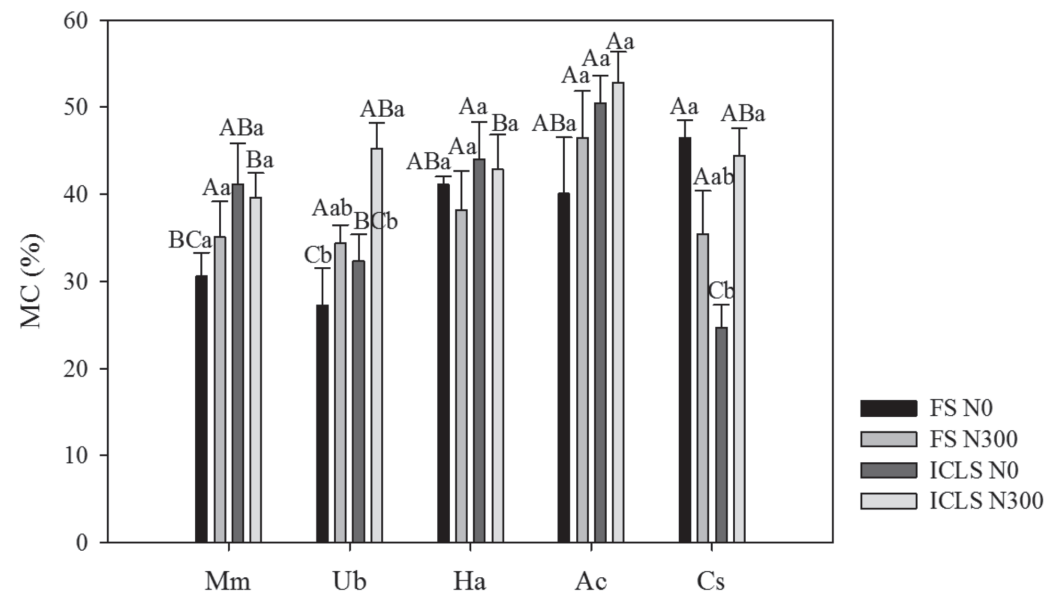

Figure 1: Means $(n=3)$ of the mycorrhizal colonization $(M C)$ by the forage species in each system (FS, full sun, $n=30$, ICLS, integrated crop-livestock system with trees, $\mathrm{n}=90)$ and at different $\mathrm{N}$ rates (N0, without nitrogen fertilization, $\mathrm{N} 300,300 \mathrm{~kg}$ of $\mathrm{N}$ ha $^{-1}$ year-1). Please refer to Table 5 for species abbreviations. Means followed by the same capital letter (compare species within each treatment) or lower case (compare treatments for each species) do not differ from each other by the Fisher test (LSD) at 5\% significance.
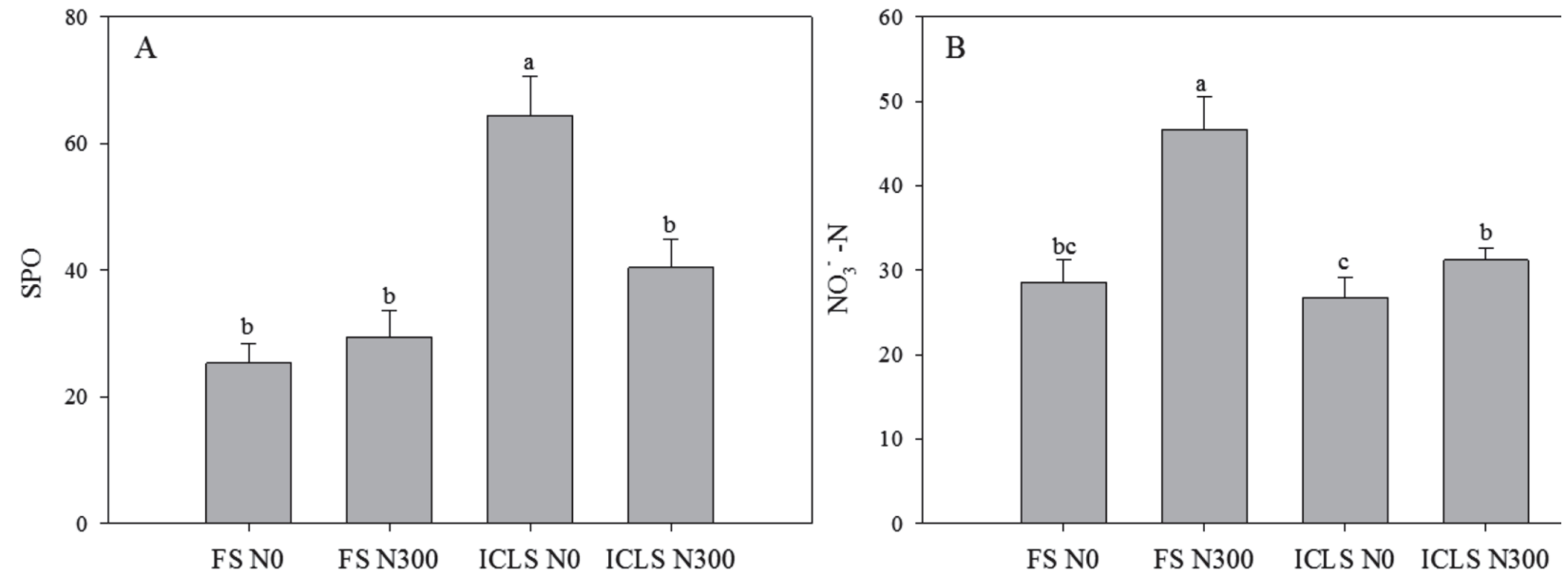

Figure 2: The sporulation averages for the arbuscular mycorrhizal fungi (A, SPO, $50 \mathrm{~mL}^{-1}$ soil) and $\mathrm{N}$ concentrations available in the soil as nitrates ( $\mathrm{B}, \mathrm{NO}_{3}^{-}-\mathrm{N}$, ìg g ${ }^{-1}$ soil) for each system (FS, full sun, ICLS, integrated crop-livestock system with trees) and $\mathrm{N}$ doses (N0, without nitrogen fertilization, $\mathrm{N} 300,300 \mathrm{~kg} \mathrm{~N}^{-1} \mathrm{year}^{-1}$ ). Means followed by the same letter do not differ from each other by the Fisher test (LSD) at 5\% significance.

Rev. Ceres, Viçosa, v. 66, n.3, p. 226-234, mai/jun, 2019 
Guadarrama \& Alvarez-Sánchez (1999) proposed that moisture encouraged spore germination, producing a high degree of colonization but poor spore yield. During the sampling period, in this experiment, a large volume of rainfall was received (Table 1), which might have affected the results. It is also noteworthy that treatments involving higher MC do not always induce increased sporulation by AMF (see Figure 1), as previously reported (Staddon et al., 2003).

Despite the variations observed in $\mathrm{CM}$ and sporulation as reported above, no significant differences $(p>0.10)$ were observed between the factors studied for easily extractable soil glomalin (EEG) and total glomalin (TG), with means of $4.89 \pm 0.137 \mathrm{mg} \mathrm{g}^{-1}$ soil and $2.55 \pm$ $0.048 \mathrm{mg} \mathrm{g}^{-1}$ soil, respectively. Also, no significant interactions were observed between the factors studied for such variables. According to Sousa et al. (2012), the mechanisms that regulate the production of glomalin by AMF are still not well understood, however, factors that affect mycorrhizal symbiosis may also affect the production of this glycoprotein. Therefore, greater sporulation, such as that occurring in ICLS, could signify a higher production of this glycoprotein. One hypothesis to explain the results obtained is that the different systems harbor different fungal species. The dominant fungal species in ICLS could invest less in the production of extraradicular hyphae (responsible for production of glomalin) and more in intraradicular structures (Sousa et al., 2012).

Acid phosphatase activity was found to be significantly reduced $(\mathrm{p}<0.05)$ in ICLS (Table 3 ), as well as in the N0 treatment (Table 4), independent of the species used (Table 5), showing that such enzymes are sensitive to land-use change. Shade provided by trees in the ICLS - as high as 56\% in relation to FS - affected pasture growth (Pontes et al., 2016). The lower production of plant biomass and the deposition of residue on the soil surface leads to lower substrate production of plant biomass to promote microbial growth and, consequently, for the production of enzymes (Balota et al., 2004). In addition, the activity of these enzymes is highly correlated with the total $\mathrm{N}$ content in the soil, since microbial activity can suffer a reduction under conditions of $\mathrm{N}$ deprivation (Dick et al., 1988). In fact, the highest levels of $\mathrm{N}$ present in the soil, mainly in nitrate form, were observed in the FS system $(\mathrm{p}<0.10$, Table 3 ) and in the N300 treatment ( $<<0.05$, Table 4). The lower N availability in the ICLS could be attributed to lower deposition of residues (aerial and root) owing to lower forage productivity. Therefore, the benefits of litter input from trees to availability of $\mathrm{N}$ in the soil were not sufficient to overcome the negative impact of high overhead sources of sunlight restriction on crop yield.

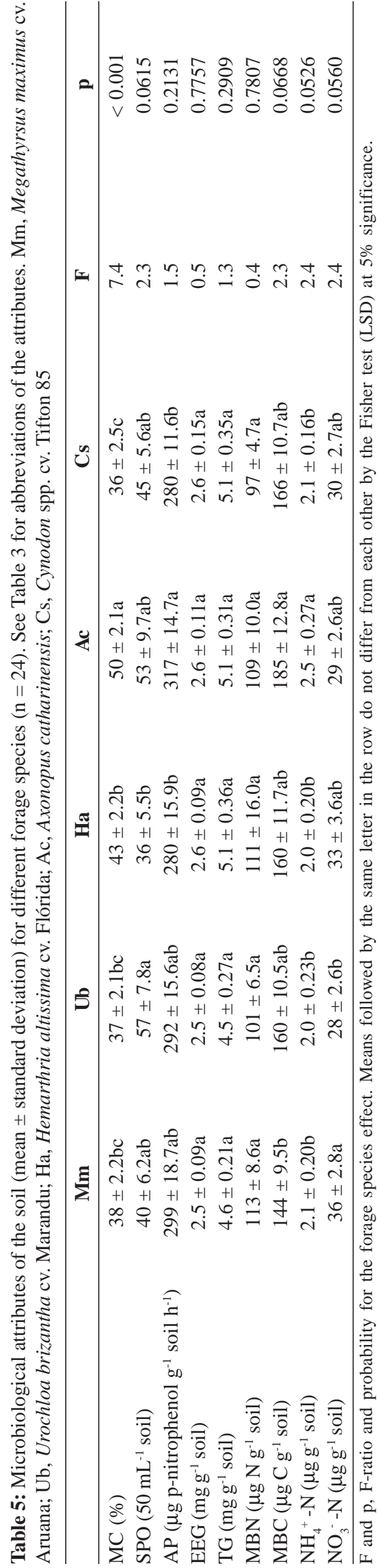

Rev. Ceres, Viçosa, v. 66, n.3, p. 226-234, mai/jun, 2019 
In addition, the $\mathrm{N}$ of the soil microbial biomass was also significantly lower in the ICLS (Table 3), particularly in the intermediate position to the trees (P5, Table 6). Despite the lower deposition of forage residues in the ICLS, and reducing the amount of mineral $\mathrm{N}$ in the soil, this residue presents a higher concentration of $\mathrm{N}$ (Pontes et al., 2016). The higher the concentration of $\mathrm{N}$ in the litter, the higher its rate of decomposition (Batista et al., 2018), and the lower the $\mathrm{N}$ that gets accumulated in the microbial biomass.

Significant interactions between the systems and $\mathrm{N}$ doses $(F=4.39, p<0.05$, Figure 2$)$ and between the species and $\mathrm{N}$ doses $(\mathrm{F}=3.32, \mathrm{p}<0.05$, Figure 3$)$ were evident for the soil $\mathrm{N}$ concentrations as nitrates. Nitrogen fertilization increased the nitrate content in the FS and ICLS systems by $63 \%$ and $17 \%$, respectively (Figure 2), the only exception being the H. altissima species (Figure 3). Pontes et al. (2017) emphasized the poor response of this species to $\mathrm{N}$ fertilization with regards to the dry matter yield.
It is clear that no remarkable differences were present between species for MBN (Table 5). With respect to MBC (Figure 3), differences among the species were more significant, in the range of $134 \pm 8.51(\mathrm{Mm}, \mathrm{N} 300)$ and 207 \pm 22.2 (Ac, N0) $\mu \mathrm{g} \mathrm{C} \mathrm{g}^{-1}$ soil. For this attribute, marked interactions were noted between the $\mathrm{N}$ doses and species $(\mathrm{F}=3.38, \mathrm{p}<0.05)$. Generally, in the $\mathrm{MBC}$, the levels were seen to decline after $\mathrm{N}$ fertilization, the exception being the H. altissima species (Figure 3). Delbem et al. (2011) also identified higher MBC values in the treatments lacking $\mathrm{N}$; they held the soil acidification responsible for this effect, after high $\mathrm{N}$ doses were applied. The higher MBC levels suggested an increased, though temporary, immobilization of the nutrients and therefore, decreased nutrient loss in the soil-plant system (Gama-Rodrigues et al., 2005).

For this variable, the differences between the tree stand positions were noted in the N300 fertilization treatment alone (Figure 4), with higher values in the intermediate position $(\mathrm{F}=4.14, \mathrm{p}<0.05)$. In the tree

Table 6: Microbiological attributes of the soil (mean \pm standard deviation) for the different positions between the tree rows $(n=30)$. Refer Table 3 for the attribute abbreviations. P2, $2 \mathrm{~m} ; \mathrm{P} 5,5 \mathrm{~m}$ and P10, at $10.5 \mathrm{~m}$ distance from the trees

\begin{tabular}{|c|c|c|c|c|c|}
\hline & $\mathbf{P 2}$ & P5 & $\mathbf{P 1 0}$ & $\mathbf{F}$ & $\mathbf{p}$ \\
\hline $\mathrm{MC}(\%)$ & $44 \pm 2.6 a$ & $39 \pm 2.4 \mathrm{a}$ & $43 \pm 1.9 \mathrm{a}$ & 1.9 & 0.1618 \\
\hline $\mathrm{SPO}\left(50 \mathrm{~mL}^{-1}\right.$ soil $)$ & $43 \pm 5.7 b$ & $58 \pm 7.3 \mathrm{a}$ & $57 \pm 7.4 \mathrm{ab}$ & 2.8 & 0.0660 \\
\hline AP $\left(\mu \mathrm{g}\right.$ p-nitrophenol $\mathrm{g}^{-1}$ soil $\left.^{-1}\right)$ & $281 \pm 11.6 \mathrm{a}$ & $269 \pm 12.6 \mathrm{a}$ & $262 \pm 8.3 \mathrm{a}$ & 0.7 & 0.5088 \\
\hline $\mathrm{EEG}\left(\mathrm{mg} \mathrm{g}^{-1}\right.$ soil $)$ & $2.5 \pm 0.10 \mathrm{a}$ & $2.5 \pm 0.13 \mathrm{a}$ & $2.5 \pm 0.10 \mathrm{a}$ & 0.2 & 0.8149 \\
\hline $\mathrm{TG}\left(\mathrm{mg} \mathrm{g}^{-1}\right.$ soil $)$ & $4.5 \pm 0.22 \mathrm{a}$ & $4.8 \pm 0.30 \mathrm{a}$ & $4.5 \pm 0.31 \mathrm{a}$ & 0.6 & 0.5700 \\
\hline $\operatorname{MBN}\left(\mu \mathrm{g} \mathrm{N} \mathrm{g}^{-1}\right.$ soil $)$ & $118 \pm 13.6 \mathrm{a}$ & $88 \pm 4.4 \mathrm{~b}$ & $91 \pm 7.0 \mathrm{~b}$ & 4.7 & 0.0112 \\
\hline $\operatorname{MBC}\left(\mu \mathrm{g} \mathrm{C} \mathrm{g}^{-1}\right.$ soil $)$ & $154 \pm 9.6 \mathrm{a}$ & $165 \pm 12.7 \mathrm{a}$ & $153 \pm 8.1 \mathrm{a}$ & 0.6 & 0.5666 \\
\hline $\mathrm{NH}_{4}^{+}-\mathrm{N}\left(\mu \mathrm{g} \mathrm{g}^{-1}\right.$ soil $)$ & $2.0 \pm 0.20 \mathrm{a}$ & $1.6 \pm 0.12 b$ & $1.7 \pm 0.14 \mathrm{ab}$ & 3.4 & 0.0363 \\
\hline $\mathrm{NO}_{3}^{-}-\mathrm{N}\left(\mu \mathrm{g} \mathrm{g}^{-1}\right.$ soil $)$ & $28 \pm 1.7 \mathrm{a}$ & $29 \pm 2.9 \mathrm{a}$ & $31 \pm 2.3 \mathrm{a}$ & 0.6 & 0.5486 \\
\hline
\end{tabular}

$\mathrm{F}$ and $\mathrm{p}, \mathrm{F}$-ratio and probability for the position effect between the tree rows. Means followed by the same letter in the row do not differ from each other by the Fisher test (LSD) at 5\% significance.
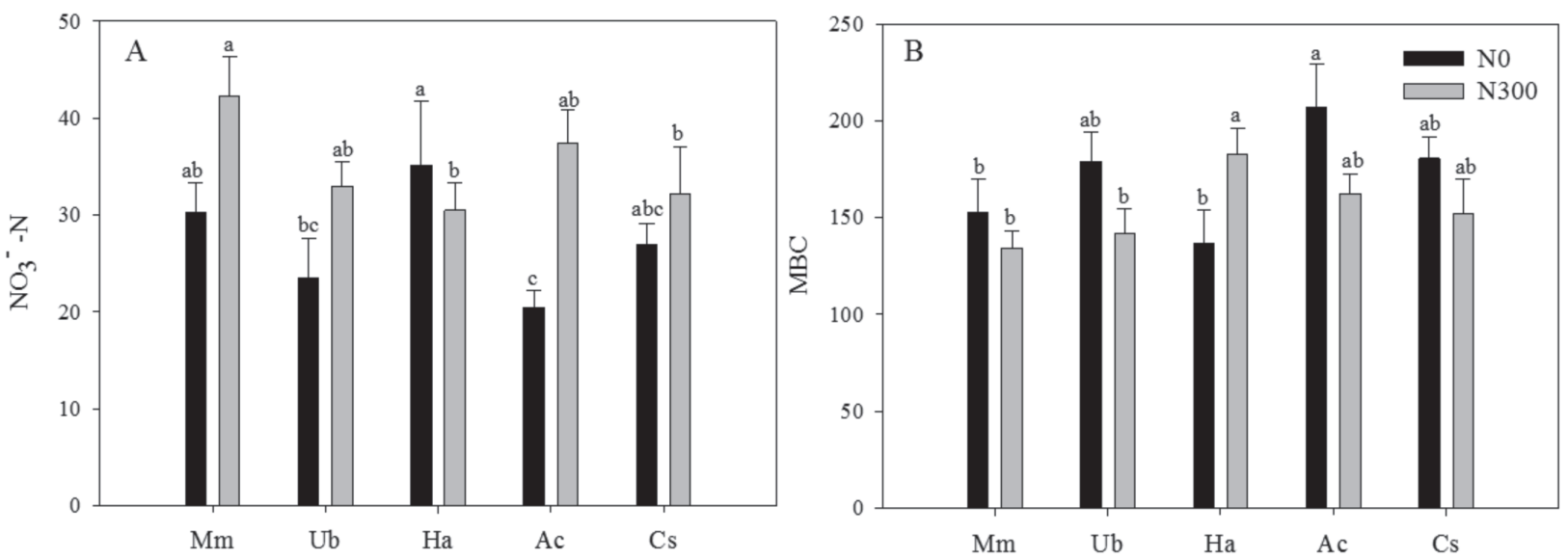

Figure 3: Means $(\mathrm{n}=12)$ of $\mathrm{N}$ concentrations available in the soil as nitrates $\left(\mathrm{A}, \mathrm{NO}_{3}^{-}-\mathrm{N}\right.$, ìg $\mathrm{g}^{-1}$ soil $)$ and soil microbial biomass carbon (B, MBC, ìg $\mathrm{C} \mathrm{g}^{-1}$ soil) for each species and $\mathrm{N}$ doses ( $\mathrm{N}$, without nitrogen fertilization, $\mathrm{N} 300,300 \mathrm{~kg}$ of $\mathrm{N} \mathrm{ha}^{-1}$ year ${ }^{-1}$ ). Refer to Table 5 for species abbreviations. Means followed by the same letter at each $\mathrm{N}$ dose do not differ from one another by the Fisher test (LSD) at $5 \%$ significance.

Rev. Ceres, Viçosa, v. 66, n.3, p. 226-234, mai/jun, 2019 


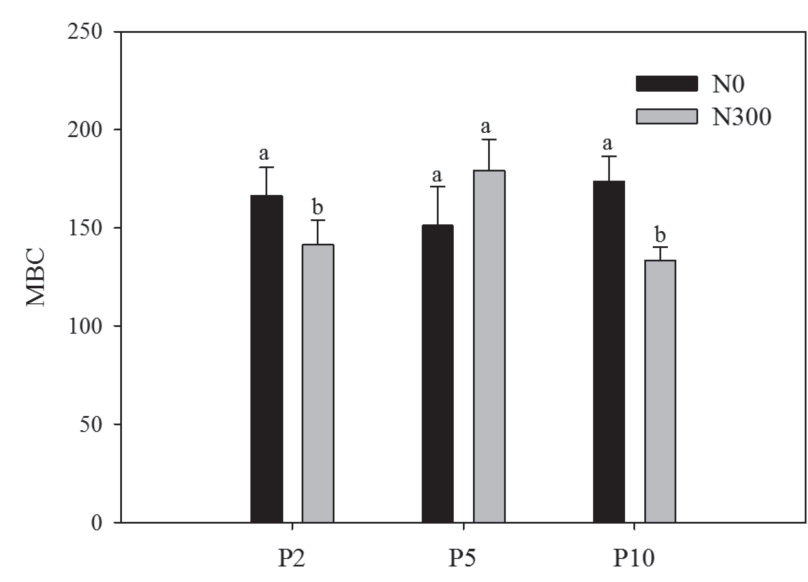

Figure 4: Means $(\mathrm{n}=15)$ of the soil microbial biomass carbon (MBC, ìg $\mathrm{C} \mathrm{g}^{-1}$ soil) for each position between the tree rows and in response to each $\mathrm{N}$ dose (N0, without $\mathrm{N}$ fertilization, $\mathrm{N} 300$, $300 \mathrm{~kg}$ of N ha ${ }^{-1}$ year ${ }^{-1}$ ). Refer Table 6 for the abbreviations of the different positions between the tree rows. Means followed by the same letter at each $\mathrm{N}$ dose do not differ from one another by the Fisher test (LSD) at 5\% significance.

systems, the differences between the positions suggest higher spatial heterogeneity.

In brief, inconsistent with our hypothesis, the microbiological attributes of the soil could not all be said to be positively influenced by their association with the $E$. dunnii trees. The high shade levels noted eight years post tree planting and the resultant negative influence on the yield of the related crops (Pontes et al., 2016), are the likely reasons for these responses. On average, in the tree system the decreased PAR was found to be $61 \pm 4.03 \%, 50 \pm 4.47 \%$ and $56 \pm 4.64 \%$ for P2, P5 and P10, respectively. Therefore, it was understood that thinning was more frequently necessary to reduce the degree of shading and thus, maximize the advantages of these integrated systems.

\section{CONCLUSIONS}

Mycorrhizal colonization, sporulation of mycorrhizal fungi and carbon contents of the microbial biomass showed a rise in soils cultivated with the forage grass species Axonopus catharinensis, which is thus another reason to include such species in the woody conservation systems.

Nitrogen fertilization on the one hand encouraged greater mycorrhizal colonization and acid phosphatase enzyme activity, while on the other, it caused the soil microbial biomass to decrease.

Compared with the system exposed to full sun (or monocultures), the integrated crop-livestock system with trees encouraged the arbuscular mycorrhizal fungi to get established, revealing higher colonization and sporulation rates. However, in this type of system the soil microbial biomass and acid phosphatase enzyme activity declined.

\section{ACKNOWLEDGMENT, FINANCIAL SUPPORT AND FULL DISCLOSURE}

The authors extend their gratitude to Giliardi Stafin and André L. O. de Francisco for the technical support rendered. The present work was performed with support from the National Council of Scientific and Technological Development (CNPq, 478160 / 2013-5). The first author is grateful to CAPES for the scholarship, and Laíse da S. Pontes is also grateful to $\mathrm{CNPq}$ for providing the grant (306628/2015-5).

\section{REFERENCES}

Araujo ASF, Leite LFC, Iwata B de F, Lira Jr M de A, Xavier GR \& Figueiredo M do VB (2012) Microbiological process in agroforestry systems. A review. Agronomy for Sustainable Development, 32:215-226.

Bainard LD, Klironomos JN \& Gordon AM (2011) Arbuscular mycorrhizal fungi in tree-based intercropping systems: A review of their abundance and diversity. Pedobiologia, 54:57-61.

Balota EL, Kanashiro M, Colozzi Filho A, Andrade DS \& Dick RP (2004) Soil enzyme activities under long-term tillage and crop rotation systems in subtropical agro-ecosystems. Brazilian Journal of Microbiology, 35:300-306.

Batista ER, Zanchi CS, Ferreira DA, Santiago FL de A, Pinto FA, Santos JV dos, Paulino HB \& Carneiro MAC (2018) Atributos biológicos do solo em sistema integrado de produção agropecuária. In: Souza ED, Silva FD, Assmann TS, Carneiro MAC, Carvalho PCF \& Paulino HB (Eds.) Sistemas integrados de produção agropecuária no Brasil. Tubarão, Copiart. p.71-90.

Bradford MM (1976) A rapid and sensitive method for the quantitation of microgram quantities of protein utilizing the principle of protein-dye binding. Analytical Biochemistry, 72:248-254.

Brookes PC, Landman A, Pruden G \& Jenkinson DS (1985) Chloroform fumigation and the release of soil nitrogen: a rapid direct extraction method to measure microbial biomass nitrogen in soil. Soil Biology and Biochemistry, 17:837-842.

Carvalho PC de F, Anghinoni I, Moraes A de, Souza ED de, Sulc RM, Lang CR, Flores JPC, Lopes MLT, Silva JLS da, Conte O, Wesp C de L, Levien R, Fontaneli RS \& Bayer C (2010) Managing grazing animals to achieve nutrient cycling and soil improvement in no-till integrated systems. Nutrient Cycling in Agroecosystems, 88:259-273.

Cordeiro MAS, Carneiro MAC, Paulino HB \& Saggin Jr OJ (2005) Colonização e densidade de esporos de fungos micorrízicos em dois solos do cerrado sob diferentes sistemas de manejo. Pesquisa Agropecuária Tropical, 35:147-153.

Delbem FC, Scabora MH, Soares Filho CV, Heinrichs R, Ferrari TA \& Cassiolato AMR (2010) Colonização micorrízica e fertilidade do solo submetido a fontes e doses de adubação nitrogenada em Brachiaria brizantha. Acta Scientiarum. Agronomy, 32:455461 .

Delbem FC, Scabora MH, Soares Filho CV, Heinrichs R, Crociolli CA \& Cassiolato AMR (2011) Fontes e doses de adubação nitrogenada na atividade microbiana e fertilidade do solo cultivado com Brachiaria brizantha. Agronomy, 33:361-367.

Dick RP, Rasmussen PE \& Kerle EA (1988) Influence of longterm residue management on soil enzyme activities in relation to soil chemical properties of a wheat-fallow system. Biology and Fertility of Soils, 6:159-164. 
Driver JD, Holben WE \& Rillig MC (2005) Characterization of glomalin as a hyphal wall component of arbuscular mycorrhizal fungi. Soil Biology \& Biochemistry, 37:101-106.

Embrapa - Empresa Brasileira de Pesquisa Agropecuária (2008) Mapa de solos do Estado do Paraná: Legenda Atualizada. Rio de Janeiro, Embrapa Solos. 74p.

Ferreira DA, Carneiro MAC \& Saggin Junior OJ (2012) Fungos Micorrízicos Arbusculares em um Latossolo Vermelho sob Manejos e Usos no Cerrado. Revista Brasileira de Ciência do Solo, 36:51-61.

Freitas ECS de, Oliveira Neto SN de, Fonseca DM da, Santos MV, Leite HG \& Machado VD (2013) Deposição de serapilheira e de nutrientes no solo em sistema agrossilvipastoril com eucalipto e acácia. Revista Árvore, 37:409-417.

Gama-Rodrigues EF da, Barros NF de, Gama-Rodrigues AC da \& Santos GA (2005) Nitrogênio, carbono e atividade da biomassa microbiana do solo em plantações de eucalipto. Revista Brasileira de Ciência do Solo, 29:893-901.

Gerdemann JW \& Nicolson TH (1963) Spores of Mycorrhizal Endogone Species Extracted from Soil by Wet Sieving and Decanting. Transaction of the British Mycological Society, 46:235-246.

Giovannetti M \& Mosse B (1980) An evaluation of techniques for measuring vesicular arbuscular mycorrhizal infection in roots. New Phytologist, 84:489-500.

Guadarrama P \& Álvarez-Sánchez FJ (1999) Abundance of arbuscular mycorrhizal fungi spores in different environments in a tropical rain forest, Veracruz, Mexico. Mycorrhiza, 8:267-270.

Hungria M, Franchini JC, Brandão-Junior O, Kaschuk G \& Souza RA (2009) Soil microbial activity and crop sustainability in a long-term experiment with three soil-tillage and two croprotation systems. Applied Soil Ecology, 42:288-296.

Kempers AJ \& Zweers A (1986) Ammonium determination in soil extracts by the salicylate method. Communications in Soil Science \& Plant Analysis, 17:715-723.

Lopes LB, Eckstein C, Pina DS \& Carnevalli RA (2016) The influence of trees on the thermal environment and behaviour of grazing heifers in Brazilian Midwest. Tropical Animal Health and Production, 48:755-761.

Miyazawa M, Pavan MA \& Block MFM (1985) Determinação espectrofotométrica de nitrato em extratos de solo sem redução química. Pesquisa Agropecuária Brasileira, 20:129-133.
Moraes A de, Carvalho PC de F, Anghinonib I, Lustosa SBC, Costa SEVG de A \& Kunrath TR (2014) Integrated crop-livestock systems in the Brazilian subtropics. European Journal of Agronomy, 57:04-09.

Pontes L da S, Giostri AF, Baldissera TC, Barro RS, Porfírio-daSilva V, Moletta JL \& Carvalho PC de F (2016) Interactive Effects of Trees and Nitrogen Supply on the Agronomic Characteristics of Warm-Climate Grasses. Agronomy Journal, 108:1531-1541.

Pontes L da S, Baldissera TC, Giostri AF, Stafin G, Santos BRC dos \& Carvalho PC de F (2017) Effects of nitrogen fertilization and cutting intensity on the agronomic performance of warmseason grasses. Grass and Forage Science, 72:663-675.

Pretty J (2018) Intensification for redesigned and sustainable agricultural systems. Science, 362:eaav0294.

Rillig MC, Ramsey PW, Morris S \& Paul EA (2003) Glomalin, an arbuscular mycorrhizal soil protein, responds to land-use change. Plant and Soil, 253:293-299.

Santos MC dos, Silva HL, Buzetti S \& Cassiolato AMR (2008) Caracterização química e microbiológica do solo e da produção de biomassa de Brachiaria brizantha, em diferentes épocas de amostragem. Pesquisa Agropecuária Tropical, 38:06-13.

Staddon PL, Thompson K, Jakobsen I, Grime JP, Askew AP \& Fitter AH (2003) Mycorrhizal fungal abundance is affected by long-term climatic manipulations in the field. Global Change Biology, 9:186-194.

Sousa C da S, Menezes RSC, Sampaio EV de SB \& Lima F de S (2012) Glomalina: características, produção, limitações e contribuição nos solos. Semina: Ciências Agrárias, 33:3033-3044.

Tabatabai MA (1994) Soil enzymes. In: Weaver R, Angle S \& Bottomeley P (Eds.) Methods of soil analysis: Microbiological and biochemical properties. Madison, Soil Science Society of America. p.778-835.

Udawatta RP \& Jose S (2012) Agroforestry strategies to sequester carbon in temperate North America. Agroforestry Systems, 86:225-242.

Vance ED, Brookes PC \& Jenkinson DS (1987) An extraction method for measuring soil microbial biomass C. Soil Biology \& Biochemistry, 19:703-707. 